\title{
Selenium content and physicochemical characterization of traditional Brazilian coalho cheese
}

Renata Carmo de Assis ${ }^{1} \oplus$, Francisco Luan Fonsêca da Silva²®, Jéssica Gadelha Reges ${ }^{1} \oplus$,

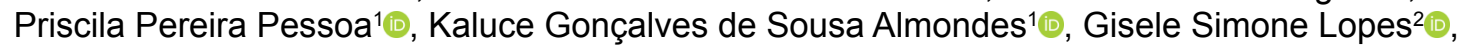

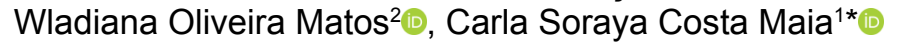

\footnotetext{
1 Universidade Estadual do Ceará, Fortaleza, CE, Brasil. E-mail: renata.carmo.assis@gmail.com; jessica.g.r_@hotmail.com; prippessoa@gmail.com; kaluce@hotmail.com; carla.maia@uece.br

${ }^{2}$ Universidade Federal do Ceará, CE, Brasil. E-mail: fluan.fonseca@gmail.com; gslopes@ufc.br; wladianamatos@ufc.br
}

ABSTRACT: Studies of centesimal composition regarding coalho. From the perspective that selenium content in foods can vary due to environmental factors and cheese may be a source of such nutrient, it is believed that is relevant to characterize the possible selenium contents in coalho cheese. The samples of cheese were collected of the and selenium was quantified by Hydride Generation Atomic Absorption Spectrometry. Protein content was determined by the Kjeldahl method and lipids by Soxhlet extraction. The centesimal composition presented variations for humidity $\left(50.5-61.9 \% \mathrm{w} \mathrm{w}^{-1}\right)$, ashes $\left(2.37-4.16 \% \mathrm{w} \mathrm{w}^{-1}\right)$, proteins $\left(14.3-19.7 \% \mathrm{w} \mathrm{w}^{-1}\right)$, lipids $\left(15.6-26.6 \% \mathrm{w} \mathrm{w}^{-1}\right)$ and for carbohydrates $\left(0.10-6.50 \% \mathrm{w} \mathrm{w}^{-1}\right)$. The selenium contents were heterogeneous among the samples (4.21-38.78 $\left.\mathrm{ug} \mathrm{kg}^{-1}\right)$. In Principal Component Analysis, it was observed that samples are divided by selenium concentrations and is justified by groups that present producer cities with different characteristics in terms of soil, average rainfall and distance from the coast. It was concluded that the samples are low-fat cheeses and sources of protein, and only the cheese from Limoeiro do Norte is a source of selenium. The samples presented distinct variations in both physicalchemical and selenium concentrations.

\section{Concentração de selênio e caracterização físico-química do queijo de coalho tradicional brasileiro}

RESUMO: Os estudos de composição centesimal do queijo coalho são escassos. Diante da perspectiva que o teor de selênio nos alimentos pode variar devido a fatores ambientais, e o queijo pode ser uma fonte de tal nutriente, acredita-se na relevância de caracterizar os possíveis teores de selênio neste queijo. As amostras de queijo foram coletadas e o selênio foi quantificado por Espectrometria de Absorção Atômica de Geração de Hidretos. $O$ teor de proteína foi determinado pelo método de Kjeldahl e os lipídios pela extração de Soxhlet. A composição centesimal apresentou variações para umidade $\left(50,5-61,9 \% \mathrm{w} \mathrm{w}^{-1}\right)$, cinzas $\left(2,37-4,16 \% w^{-1} w^{-1}\right.$, proteínas $\left(14,3-19,7 \% w^{-1}\right)$, lipídios $\left(15,6-26,6 \% w^{-1}\right)$ e para carboidratos $\left(0,10-6,50 \% w^{-1}\right) .0$ conteúdo de selênio foi heterogêneo entre as amostras $\left(4,21-38,78 \mu \mathrm{g} \mathrm{kg}^{-1}\right)$. Na Análise dos Componentes Principais, observase que as amostras são divididas por concentrações de selênio, justificada por grupos que apresentam cidades produtoras com características diferentes em termos de solo, precipitação média e distância da costa. Conclui-se que as amostras são queijos magros e e fontes proteicas, e apenas de Limoeiro do Norte é uma fonte de selênio. As amostras apresentaram variações distintas nas concentrações físico-químicas e de selênio.

Palavras-chave: queijo regional brasileiro; gordura; proteína

\footnotetext{
*Carla Soraya Costa Maia - E-mail: carla.maia@uece.br (Corresponding author)

Associate Editor: Severino Matias de Alencar
} 


\section{Introduction}

Bovine milk is a common food component in human diets, providing about $66 \mathrm{kcal} 100 \mathrm{~mL}^{-1}$, as well as being a source of vitamin $A, D$ and $B$ complex, containing macrominerals such as $\mathrm{Ca}, \mathrm{K}, \mathrm{Na}$ and $\mathrm{P}$, and microminerals such as $\mathrm{Cu}, \mathrm{Fe}, \mathrm{Mn}$ and $\mathrm{Zn}$ in its composition (Mahan et al., 2012).

Cheese is derived from milk and produced by coagulation after undergoing specific technological procedures with enzymes. The obtained curd has a chemical composition quite different from milk, which makes cheese a complex dairy product containing protein, lipids, minerals, vitamins and polyphenolic compounds, as well as beneficial physiological properties on bone health, anti-hypertensive and anti-cancer agents (McSweeney et al., 2017).

There are different kinds of cheeses, which depend on the way that it is produced, the animal from which milk derived, form of the enzymatic transformation, time of maturation, among other factors (McSweeney et al., 2017). The coalho cheese is a typical and very popular Northeastern product. It is mainly produced in the Brazilian states of Ceará, Rio Grande do Norte, Paraíba and Pernambuco. Coalho cheese has been produced on a large scale in artisanal and industrial way, and it is currently broadly spread throughout the Brazilian territory. This kind of cheese is widely consumed raw, roasted or fried and used in several culinary preparations.

Cheese classified as coalho (Brazilian traditional curd) cheese is obtained by the coagulation of the milk by means of curd or other appropriate coagulating enzymes, complemented or not by the action of selected milk bacteria, and normally commercialized within up to ten days of manufacture. It is a cheese of medium to high humidity, with a semi-cooked or cooked mass and presenting a fat content in the total solids which varies between 35 and $60 \% \mathrm{w} \mathrm{w}^{-1}$ (Brazil, 2001).

Coalho cheese is an important Brazilian gastronomic patrimony, because it carries with it the history of a knowhow, joining the product-producer-space of production (Cruz \& Hespanhol, 2018). Despite its importance in the Brazilian food tradition, there are few studies about the nutritional characteristics of coalho cheese. Consequently, it is not presented in specialized nutritional tables, representing an immense gap in the characterization of this industrial product of human consumption.

Micronutrients deficiency is a public health problem in Northeastern Brazil and serum selenium levels may be associated with the occurrence of anemia in adults and children (Semba et al., 2009). In the study by Jardim-Botelho et al. (2016) on micronutrient deficiencies, $67 \%$ of children were anemic and $91 \%$ of them with selenium deficiency. Thus, regional foods such as coalho cheese could be widely consumed by the population, as well as offered as a source of fatty acids, iodine and selenium in public school meals (Średnicka-Tober et al., 2016).

As in milk, it is expected to find in the cheese a good source of macro and micronutrients which are essential for human nutrition, one of them being selenium, an essential micromineral. Selenium is a fundamental element for the proper functioning of human and animal organisms (Kieliszek \& Blazejak, 2016), and its recommended value is $55 \mu$ day $^{-1}$ in human diets (Institute of Medicine, 2000). Biological functions of selenium include defense against oxidative stress, potentiation of immune mechanisms, regulation of thyroid hormones action, participation in enzymatic processes related to reproduction and fertility, detoxification of the organism against heavy metals and xenobiotics (Kieliszek \& Blazejak, 2016).

A review of recent literature about the content of Se in different Brazilian foods reported the degree of variation in the concentration of this element in its main sources. They cited only one work that studied Brazilian milk samples and no work about cheese from this country. The authors emphasized that none of the studies cited by this review brings data of the selenium content in samples from Ceará or even from the Brazilian northeast (Santos et al., 2017).

In this context, the objective of this study was to characterize the bovine coalho cheese originated and produced in the state of Ceará - Brazil through the determination of selenium concentration and centesimal composition in coalho cheese samples from different cities of Ceará - Brazil.

\section{Materials and Methods}

Samples and reagents

Samples of bovine coalho cheese were collected in eight cities of Ceará state which are main dairy basins. The period of sample collection was from 2012 to 2014.

Samples of bovine coalho cheese from the Itapipoca city came from two different producers. The other cheese samples were collected from only one producer per municipality, which were: Cratéus, Crato, Fortaleza, Iguatu, Limoeiro do Norte and Quixadá, representing the biggest milk basin in the state. All the coalho cheese samples were homemade.

During the sampling period, the farmers used mainly forage planted in their municipalities to feed the dairy cattle.

Solutions were prepared using ultrapure water (18.2 $\mathrm{M} \Omega$ $\mathrm{cm}$ resistivity) obtained from a Milli- $\mathrm{Q}^{\circ}$ water purification system (Millipore, Bedford, MA, USA). All glassware was immersed in nitric acid $10 \% \mathrm{v} \mathrm{v}^{-1}$ (Vetec, Rio de Janeiro, Brazil) for 24 hours and rinsed with ultrapure water.

For quantification of Se, the samples were digested using $65 \% \mathrm{w} \mathrm{w}^{-1}$ nitric acid (Vetec) and $37 \% \mathrm{w} \mathrm{w}^{-1}$ hydrochloric acid (Sigma Aldrich, Germany). Sodium hydroxide $98 \% \mathrm{w} \mathrm{w}^{-1}$ (Dinâmica, São Paulo, Brazil), boric acid $98 \% \mathrm{w} \mathrm{w}^{-1}$ (Vetec) and hydrochloric acid $37 \% \mathrm{w} \mathrm{w}^{-1}$ (Vetec) were used for the determination of Se using hydride generation method. Standard calibration solutions were prepared after successive dilutions of their $1000 \mathrm{mg} \mathrm{L}^{-1}$ Se stock solutions (Acros Organics, Belgium). For the accuracy test, we used Standard Reference Material (SRM) NIST 1549a - Whole Milk Powder.

\section{Instrumentation}

The samples were freeze-dried in a Liotop Model L101 (São Carlos, São Paulo, Brazil) and ground using a mortar. A 
nitrogen distiller (Tecnal-TE-036/1, Brazil) was used for protein quantification and a Soxhlet extractor (Diadema, São Paulo, Brazil) was used for lipids quantification. The samples were decomposed in a Tecnal TE-007D digestion block (Piracicaba, São Paulo, Brazil) equipped with 15 Teflon tubes (volume capacity of $50 \mathrm{~mL}$ ) with lids.

A muffle furnace EDG-300 (EDG, São Carlos, São Paulo, Brazil) was used in ash content determination and a dry-oven SL100 (SOLAB, São Paulo, Brazil) was used in the procedure of moisture determination.

A Hitachi-Z 5000 flame atomic absorption spectrometer (Krefeld, Germany) equipped with a hydride generation system was used for selenium determination. We used a Selenium hollow cathode lamp operating at an electric current of $10 \mathrm{~mA}$ and all measurements were carried out at $196 \mathrm{~nm}$. A spectral slit-width of $1.3 \mathrm{~nm}$ and a deuterium lamp was used in background correction. The flame composition was acetylene (flow rate $2.0 \mathrm{~L} \mathrm{~min}^{-1}$ ) and air (flow rate $15.0 \mathrm{~L} \mathrm{~min}^{-1}$ ).

\section{Sample preparation for Se quantification}

The coalho cheese samples were freeze-dried, ground and stored in decontaminated vials until they were analyzed.

For decomposition of cheese samples, we added about $500 \mathrm{mg}$ of dried sample in a capped Teflon tube with $6 \mathrm{~mL}$ of $\mathrm{HNO}_{3} 65 \% \mathrm{w} \mathrm{w}^{-1}$ and $1 \mathrm{~mL}$ of $\mathrm{HCl} 37 \% \mathrm{w} \mathrm{w}^{-1}$. The mixture was left overnight and then heated for $12 \mathrm{~h}$ at $150{ }^{\circ} \mathrm{C}$. Thereafter, $5 \mathrm{~mL}$ of $1.2 \mathrm{~mol} \mathrm{~L}^{-1} \mathrm{HCl}$ was added to the solutions which were then submitted to heating again for $1 \mathrm{~h}$ at $90{ }^{\circ} \mathrm{C}$ to oxidize the Se species to Se (IV). The final solutions were diluted up to 50 $\mathrm{mL}$ using ultrapure water.

The certified reference material sample was digested using the same procedure described for cheese samples.

\section{Determination of centesimal composition}

Analyses of moisture and ash were performed according to the methodology of Instituto Adolfo Lutz (2008). Protein analysis was performed according to Kjeldahl (AOAC, 1997), lipids according to Soxhlet (AOAC, 1997) and carbohydrates were analyzed by difference (Brazil, 2003).

\section{Results and Discussion}

\section{Accuracy test for selenium determination}

The analysis of SRM NIST-1549a: Whole Milk Powder was performed in order to verify the accuracy of selenium quantification in coalho cheese samples by Hydride Generation Atomic Absorption Spectrometry (HG-AAS).

The value of selenium obtained was $0.240 \pm 0.034 \mu \mathrm{g}$ $\mathrm{kg}^{-1}(\mathrm{n}=3)$. This concentration is statistically similar $(95 \%$ of confidence) to the certified reference material value $(0.242$ $\pm 0.026, k=2$ ). These results show the accuracy of selenium analysis in this method.

Determination of centesimal composition and selenium content in coalho cheese

Brazil being an important milk producer (IBGE, 2020a), studying selenium in dairy products may present different perspectives and contexts, from the issue of enriching food with selenium so that its consumption can guarantee the homeostasis of the human body and prevent various disorders (Kieliszek, 2019), until the supplementation of the cows' diet with Se, enabling a production of milk that ensures the content of this micronutrient in the cheese (Ling et al., 2017) or simply investigating and knowing macronutrient and micronutrient aspects of the different cheeses, in which the quantification of Se is included (O'Callaghan et al., 2017).

It is observed in literature the scarcity of data on the selenium content of various types of food, including cheeses. O'Callaghan et al. (2017), for example, studied nutritional aspects of 21 types of cheeses, characterizing the physicalchemical composition, in addition to 12 vitamins and 7 minerals, and Se was not analyzed. Our study presents the data of centesimal composition and selenium content of the Brazilian Northeast coalho cheese (Table 1).

The data of moisture showed that this cheese was at the limit allowed in legislation (Brazil, 2001) for coalho cheese (between $30 \%$ and $60 \% \mathrm{w} \mathrm{w}^{-1}$ ), a factor that may favor microbiological contamination in case of inadequate storage. It presents a high protein content, presenting values that support daily protein requirements and which may be increased during the pasteurization process (Marques et al., 2020).

According to Ordinance no 146/1996 (Brazil, 1996), with the exception of the coalho cheese produced in Fortaleza, all other cheeses are classified as low-fat (lipid content $<10$ to $24.9 \%)$, remembering that milk fat is influenced by genetic, environmental and management factors (nutrition, breed and age of the dairy animal).

Few local data about centesimal composition of coalho cheese are found in the literature, but data about others cheese compositions can be summarized in Table 2 .

Table 1. Centesimal composition and Selenium content in coalho cheese.

\begin{tabular}{|c|c|c|c|c|c|c|}
\hline \multirow{2}{*}{ Municipality } & Moisture & Ashes & Protein & Lipids & Carbohydrates & \multirow{2}{*}{$\begin{array}{c}\text { Selenium } \\
\left(\mu \mathrm{g} 100 \mathrm{~g}^{-1}\right)\end{array}$} \\
\hline & \multicolumn{5}{|c|}{$\left(\% w w^{-1}\right)$} & \\
\hline Crateús & $61.9 \pm 0.3$ & $2.85 \pm 0.01$ & $14.3 \pm 0.4$ & $19.0 \pm 0.3$ & $1.98 \pm 0.55$ & $4.76 \pm 0.35$ \\
\hline Crato & $60.0 \pm 0.1$ & $3.70 \pm 0.13$ & $15.7 \pm 0.3$ & $20.2 \pm 0.4$ & $0.37 \pm 0.49$ & $4.21 \pm 0.08$ \\
\hline Iguatu & $56.0 \pm 0.5$ & $3.80 \pm 0.11$ & $17.8 \pm 0.1$ & $18.7 \pm 0.4$ & $3.72 \pm 0.16$ & $5.83 \pm 0.48$ \\
\hline Itapipoca 1 & $58.1 \pm 0.2$ & $3.09 \pm 0.06$ & $14.8 \pm 0.5$ & $19.8 \pm 0.1$ & $4.28 \pm 0.59$ & $8.74 \pm 0.16$ \\
\hline Quixadá & $56.8 \pm 0.1$ & $4.16 \pm 0.14$ & $15.09 \pm 0.05$ & $20.8 \pm 0.22$ & $3.16 \pm 0.30$ & $7.81 \pm 0.98$ \\
\hline
\end{tabular}

(mean $\pm \mathrm{SD}, \mathrm{n}=3$ ); SD (standard deviation). 
When comparing the centesimal composition data of this study with the recent data on coalho cheese from Silva et al. (2020) and Pimentel (2019) studies, variations in all data are observed, representing a lack of standardization in manufacturing processes, a characteristic of artisanal cheeses which can lead to cheeses unfit for consumption, due to the high microbiological load of the product (Silva, 2019).

The composition of minas frescal cheese is similar to values found in coalho cheese, once both cheese using curd for coagulation of milk and are traditional in Brazil, but all cheeses are good sources of protein and lipids, as the coalho cheese.

Handmade and traditional cheeses are increasingly common in Brazilian territory. Recently, five new food products have received a stamp that identifies the origin of the product, allowing consumers to have reliable information about the quality and authenticity of what they are acquiring, being among these products the cheese from Witmarsum Colony in Paraná, where markets throughout the national territory are provided (IBGE, 2020b). From this perspective, in the Northeast, only the Jaguaribe coalho cheese is in the process of receiving the seal of origin (Cruz \& Hespanhol, 2018).

The recommended daily intake varies according to the type of cheese, since the centesimal composition is different. For example, the recommendations for mozzarella are 30 and $50 \mathrm{~g} \mathrm{day}^{-1}$ for minas frescal cheese, since the amount of lipids is lower in the second case. This recommendation can be taken to Brazilian cheese curd as it has a composition similar to minas.

The activity of Se in the human body depends on an adequate selenium supply from the diet. The recommendation for Se is 55 ug day ${ }^{-1}$, thus the percentages of recommended daily allowance (\%RDA) represented by the samples are between $7.65 \%$ (Crato) and $70.5 \%$ (Limoeiro), revealing a several heterogeneity of selenium content in this cheese samples. This value is lower than the tolerable upper intake level (UL) (400 ug per day) which makes the consumption of this type of cheese safe even above the recommended consumption, taking into account the content of selenium.

Se belongs to a group of elements considered non-essential for plants, but they are part of the diet of men and animals, it can be found in low amounts in soils and its correction is necessary (Silva et al., 2012). From this perspective, the constant consumption of fruits and wild animals, as well as the inexistence of agricultural soil correction, can lead to the incidence of lithological or geochemical anomalies (Silva et al., 2006).

Selenium analyses in coalho cheese were not found in the literature, so the results were compared with other types of cheese. It was reported $7.2 \mu \mathrm{g} 100 \mathrm{~g}^{-1}$ Se in cottage cheese from Poland (Pilarczyk et al., 2010); 8.8 and $37.2 \mu \mathrm{g} 100 \mathrm{~g}^{-1}$ Se in Edam cheese from Poland and Estonia (Pilarczyk et al., 2010; Ling et al., 2017), respectively; $17.0 \mu \mathrm{g} 100 \mathrm{~g}^{-1} \mathrm{Se}$ in mozzarella cheese (IBGE, 2011) and $1.5 \mu \mathrm{g} 100 \mathrm{~g}^{-1}$ Se in Monterey Jack cheese (United States Department of Agriculture, 2013), both from EUA. A high heterogeneity can be observed in Se content in cheese from different parts of the world. Even the same type of cheese (Edam) shows very different values when produced in different countries.

Table 1 shows variations of Se concentration among samples from different regions of Ceará. This occurred even between cheeses of the same producer city (Itapipoca 1 and 2).

High concentrations of Se were observed in the samples from Limoeiro do Norte, extremely different from the values observed in the other municipalities of the study.

Considering there are no differences in the type of cattle feed, and that the three years of collection were years of drought in the state, it can be estimated that the variation of Se content in coalho cheese samples reflected the level of selenium of the soils where the forage used to feed the cattle was planted.

Moatkhef et al. (2020) found an average of $82 \mu \mathrm{g} 100 \mathrm{~g}^{-1}$ of Se in the group of milks and derivatives and emphasized that the content of Se in the different food groups studied were not only correlated with the composition of the soil and the

Table 2. Centesimal composition of different types of cheese found in the literature.

\begin{tabular}{|c|c|c|c|c|c|}
\hline \multirow{2}{*}{ Cheese } & Moisture & Ashes & Protein & Lipids & Carbohydrates \\
\hline & \multicolumn{5}{|c|}{$\left(\% \mathrm{~m} \mathrm{~m}^{-1}\right)$} \\
\hline Coalho (Silva et al., 2020) & $39.6 \pm 0.8$ & $4.6 \pm 0.1$ & $22.6 \pm 2.5$ & $26.4 \pm 0,6$ & $7.5 \pm 2.1$ \\
\hline Coalho (Silva, 2019) & 43.2 & 3.7 & 14.1 & 27.1 & 11.9 \\
\hline Artisanal from Paraná (Castilho et a., 2019) & 39.1 & 4.3 & 20.2 & 27.8 & 8.7 \\
\hline Minas Frescal (TACO, 2011) & 56.1 & 3.0 & 17.4 & 20.2 & 3.5 \\
\hline Minas (Goat) (Sant'Ana et al., 2013) & $64.0 \pm 2.4$ & $2.3 \pm 0.3$ & $15.8 \pm 0.8$ & $16.4 \pm 0.7$ & 1.6 \\
\hline Mozzarela (USDA, 2013) & 46.4 & 3.71 & 24.2 & 23.9 & 2.0 \\
\hline Parmesan (TACO, 2011) & 21.2 & 8.8 & 35.6 & 33.5 & 0.9 \\
\hline Prato (TACO, 2011) & 42.4 & 3.9 & 22.7 & 29.1 & 1.9 \\
\hline Ricotta (TACO, 2011) & 73.6 & 1.9 & 12.6 & 8.1 & 3.8 \\
\hline Tofu (Soybean cheese) (TACO, 2011) & 86.6 & 6.6 & 4.0 & 0.7 & 2.1 \\
\hline Curd in powder (USDA, 2013) & 1.1 & 6.9 & 0.4 & 85.6 & 6.0 \\
\hline
\end{tabular}


process of soil fortification, but were also strongly correlated with the food matrix and composition of these foods. These values found are much higher than those of the coalho cheese under study and are characterized as a soil with higher contents of Se and a food matrix predisposing to this mineral.

The data obtained were used for the creation of models using principal component analysis (PCA). The data was autoscaling and the Loadings and Scores graphs are shown in Figure $1 \mathrm{~A}$ and $1 \mathrm{~B}$.

The PCA contains $76,28 \%$ of original data and it was enough to separate groups and meets the general requirement of cumulative percent variation (CPV) $>70 \%-85 \%$ for PCA analysis (Gu et al., 2020).

Unlike the confirmation of similar groups formed in this study, Castilho et al. (2019), when analyzing the centesimal composition of artisanal cheese in 21 cheese producers, concluded that there was no relationship between the cheeses of the same producing region, confirming the absence of a standard for the manufacture of these cheeses that are produced artisanal. Thus, a similarity in the production of coalho cheese from the dairy basins of Ceará stands out.
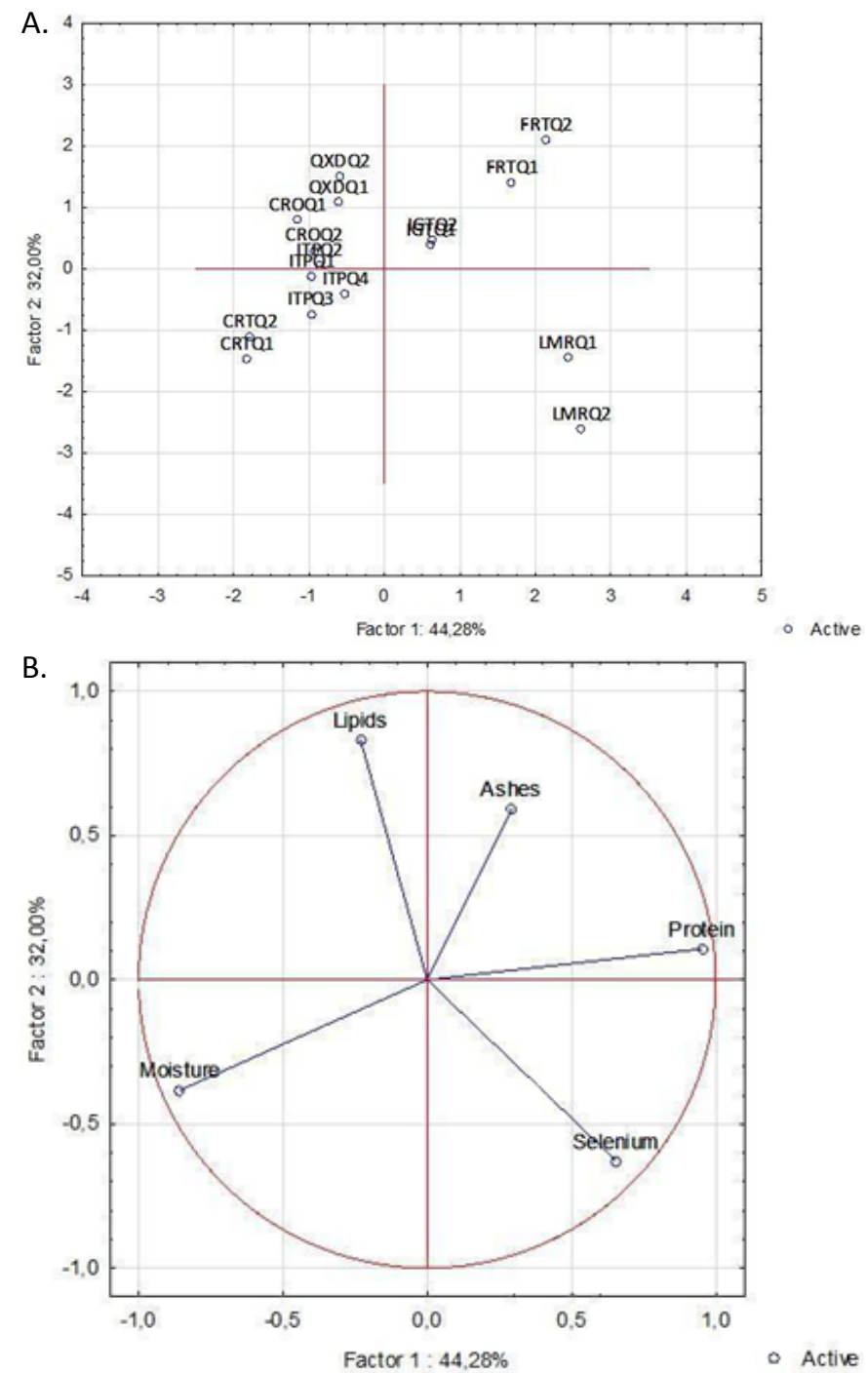

Figure 1. Graph of scores (1A) and loadings (1B) for PCA $1 \mathrm{x}$ PCA2.
The source of selenium for cattle is feed, and the relationship between soil-plants is well studied in the literature. Selenium content in soils is related to environmental factors such as rainy periods, distance from the sea and soil properties that can volatilize Se to the atmosphere (Hawrylak-Nowak, 2013; Jones et al., 2017; Ogra et al., 2017).

Limoeiro do Norte city samples show extremely high Se concentration, differentiating them in an isolated group. The municipality of Limoeiro do Norte is characterized by the presence of mangroves of the Chapada do Apodi upland and bathed by the basins of Banabuiu river, medium and low Jaguaribe river and the presence of cambisols and vertisols soils with low $\mathrm{pH}$, low rainfall and high salinity of the waters (Fundação Cearense de Meteorologia e Recursos Hídricos, 2020).

This data of Limoeiro do Norte city does not present high residues values or discordant Mahalanobis distances, even so this sample highly influences the data, thus, removing these samples obtained new profiles of main components. The new principal components were shown in Figure 2A and 2B.
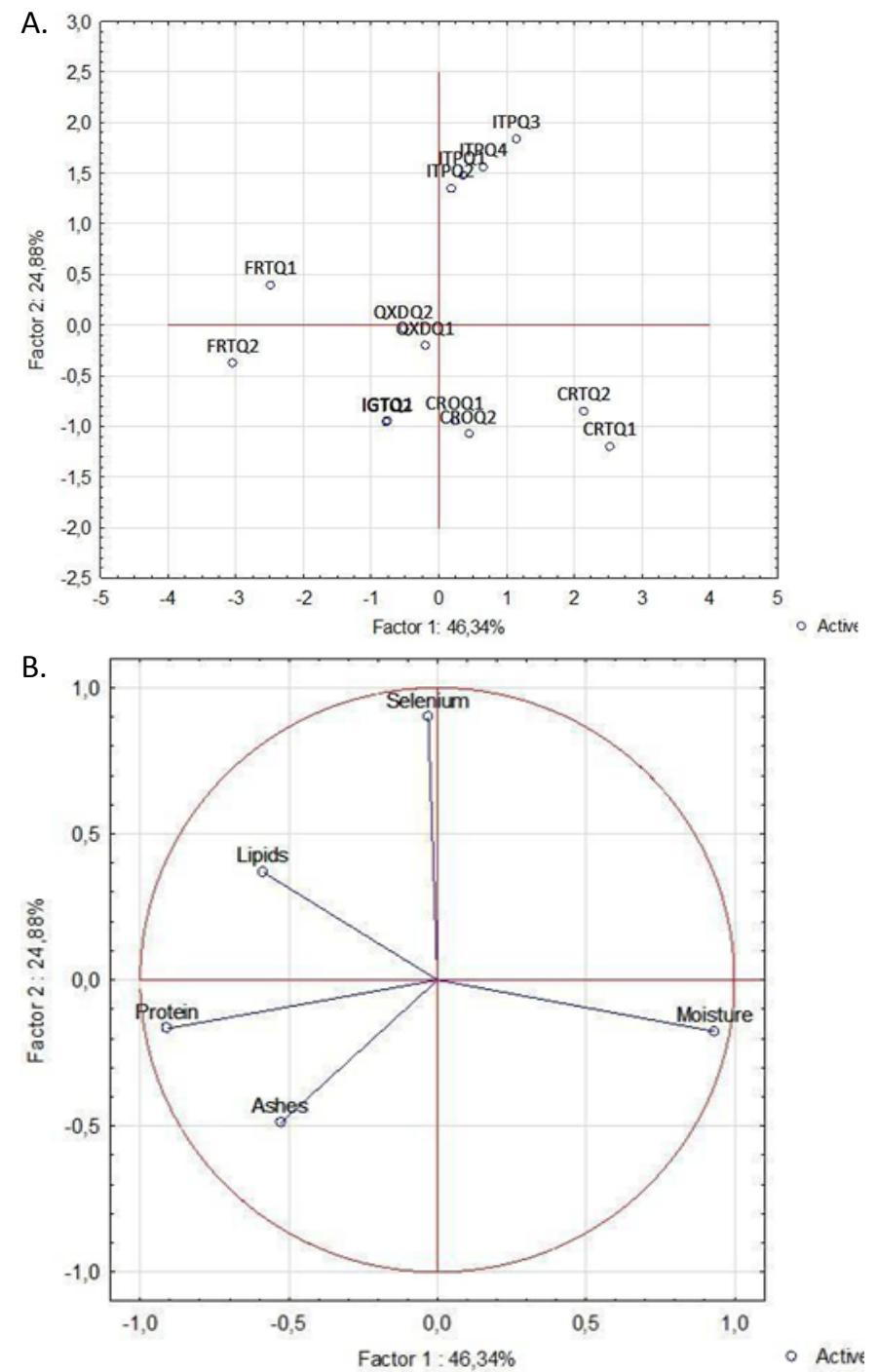

Figure 2. Graph of scores (2A) and loadings (2B) for PCA $1 \mathrm{X}$ PCA 2 without Limoeiro do Norte samples. 
The samples of Crateús, Crato, and Iguatu cities are from a region with low rainfall, distant from the seacoast factors that decrease the bioavailability of Se to be absorbed by the plants, which explain this group separation. The municipalities of Fortaleza and Itapipoca cities are coastal municipalities with high rainfall and soils rich in minerals, which helps the availability of Se. Itapipoca municipality is close to the coast and has a mangrove ecosystem then this can be enhanced the bioavailability of $\mathrm{Se}$ in plants and consequently this data presented the highest concentration of this mineral in this municipality. Fortaleza city has been located at a cost, but the high pluviometry became the Se bioavailability lower than municipalities with mangroves. The municipality of Quixadá is located nearby to the center of PCA, so it might be inferred that the variables are not significant to separate this data in a group.

The selenium content can differentiate the origin of the coalho cheese within the State, indirectly demonstrating the heterogeneity of distribution of this mineral in the soil of the cities producer of coalho cheese. However, a detailed investigation using a larger number of samples should be performed to establish these parameters with greater reliability, since this distribution can be affected by the rainy season. Furthermore, this data can represent the existence of several methods to produce this kind of traditional cheese and how this production affects the final composition of cheese.

The species of selenium naturally presented in the soil or the type of supplementation performed in cattle food directly influence the concentrations of selenocysteine (SeCys) and selenomethionine (SeMet) in the animal's blood and consequently in milk and dairy products. It is also noted that the significant increase of Se in milk and cheese is associated with the substitution of inorganic Se supplementation by organic Se in pastures (Phipps et al., 2008), and this is explained by the greater efficiency in the absorption of the latter element by the roots of the plants that will be used to feed cattle (Boldrin et al., 2012).

The absence of investigation of the soil where the fodder was harvested to feed the dairy cattle, as well as the absence of measurements of blood biomarkers of the cattle can be presented as limitations of the work, because with these data the differences between the cheeses studied could be explained.

The results were presented to fill a gap in coalho cheese characterization studies by providing data of Se content in coalho cheese from the state of Ceará, previously unavailable. This information can be used for further studies and also for use in national and regional databases.

\section{Conclusion}

It is concluded that the samples are considered low-fat cheeses and are important sources of protein.

The cheese from the city of Limoeiro do Norte is a considerable source of selenium.

The samples presented distinct variations in physicalchemical and selenium concentrations.

\section{Acknowledgments}

The authors are grateful to State University of Ceará (UECE), Cearense Foundation for Scientific and Technological Development Support (FUNCAP) for the scholarships and Coordination of Higher-Level Personnel (CAPES) for providing funds to this research.

\section{Compliance with Ethical Standards}

Funding: Cearense Foundation for Scientific and Technological Development Support (FUNCAP) and Coordination of Higher-Level Personnel (CAPES) - Finance Code (Process: 23038.000509/2020-82).

Conflict of interest: There are no conflict of interest between the authors.

Author contribution: Conceptualization: RCA, JGR, CSCM; Data curation: FLFS, GLS, CSCM; Formal analysis: GLS; Funding acquisition: CSCM, WOM; Investigation: JGR, PPP, KGSA; Methodology: JGR, PPP, KGSA; Project administration: CSCM; Resources: CSCM; Supervision: CSCM, GLS, WOM; Validation: CSCM, KGSA; Visualization: RCA, FLFS; Writing - original draft: RCA, FLFS; Writing - review \& editing: CSCM, GLS, WOM, RCA, FLFS.

\section{Literature Cited}

Association of Official Analytical Chemists - AOAC. Official Methods of Analysis. 13.ed. Wasthington. AOAC. 1997. 858p. https:// www.law.resource.org/ pub/u

Boatto, D.A.; Mesomo, M.C.; Madrona, G.S.; Branco, I.G.; Matumoto-Pintro, P.T. Characterization and elaboration of ordinary soy and lipoxigenase-free soybean petit suisse cheese enriched with calcium. Ciência e Tecnologia de Alimentos, v.30, n.3, p.766-770, 2010. https://doi.org/10.1590/S010120612010000300031.

Boldrin, P.F.; Faquin, V.; Ramos, S.J.; Guilherme, L.R.G.; Bastos, C.E.A.; Carvalho, G.S.; Costa, E.T.S. Selenate and selenite on yield and agronomic biofortification with selenium in rice. Pesquisa Agropecuária Brasileira, v..47, n.6, p.831-837, 2012. https://doi. org/10.1590/S0100-204X2012000600014.

Brazil. Ministério da Saúde. Agência Nacional de Vigilância Sanitária - ANVISA. Resolução RDC no 360, de 23 de dezembro de 2003. Aprova o regulamento técnico sobre rotulagem nutricional de alimentos embalados. Diário Oficial da União, v.140, n.251, seção 1, p.33-34, 2003. http://bvsms.saude.gov.br/bvs/ saudelegis/anvisa/2003/res0360_23_12_2003.html. 22 Jun. 2020.

Brazil. Ministério da Agricultura e Abastecimento e da Reforma Agrária. Portaria no 146 de 7 de março de 1996. Aprova os regulamentos técnicos de identidade e qualidade dos produtos lácteos. Diário Oficial da União, v.134, n.48, seção 1, p.39773986, 1996. https://www.defesa.agricultura.sp.gov.br/ legislacoes/portaria-mapa-146-de-07-03-1996,669.html. 22 Jun. 2020. 
Brazil. Ministério da Agricultura e do Abastecimento. Secretaria de Defesa Agropecuária, Instrução Normativa $n^{\circ} 30$, de 26 de junho de 2001. Aprova o regulamento técnico de identidade e qualidade de manteiga da terra ou manteiga de garrafa B. Diário Oficial da União, v.138, n.136E, seção 1, p.13-15, 2001. https://www. defesa.agricultura.sp.gov.br/legislacoes/instrucao-normativa-n30-de-26-de-junho-de-2001,1039.html. 22 Jun. 2020.

Castilho, A.C.B.; Stafussa, A.P.; Rodrigues, L.M.; Ressutte, J.B.; Pozza, M.S.S.; Madrona, G.S. Queijos artesanais do Paraná: caracterização de sua composição centesimal até a produção por laticínios, se distanciando do apelo artesanal. Brazilian Journal of Development, v.5, n.10, p.21543-21567, 2019. https://doi. org/10.34117/bjdv5n10-306.

Cruz, B.E.V.; Hespanhol, R.A.M. Indicação geográfica e queijos artesanais : marco legal e desafios a uma política para este segmento no Brasil. Confins, n. 37, 2018. https://doi.org/10.4000/confins.15222.

Fundação Cearense de Meteorologia e Recursos Hídricos. Relação de projetos concluídos da área de recursos hídricos. http://www. funceme.br/?page_id=2807. 12 Jun. 2020.

Gu, H.; Yin, X.; Ma, Y.; Wang, J.; Yang, F.; Sun, W.; Ding, B.; Chen, Y.; Liu, Z. Differentiating grades of Xihu Longjing teas according to the contents of ten major components based on HPLC-DAD in combination with chemometrics. LWT, v.130, e109688, 2020. https://doi.org/10.1016/j.lwt.2020.109688.

Hawrylak-Nowak, B. Comparative effects of selenite and selenite on growth and selenium accumulation in lettuce plants under hydroponic conditions. Plant Growth Regulation, v.70, p.149157, 2013. https://doi.org/10.1007/s10725-013-9788-5.

Institute of Medicine. Dietary reference intakes for vitamin c, vitamin e, selenium, and carotenoids. Washington: National Academies Press, 2000. https://www.ncbi.nlm.nih.gov/books/NBK225483. 29 Jun. 2020.

Instituto Adolfo Lutz. Normas Analíticas do Instituto Adolfo Lutz, Métodos físico-químicos para análise de alimentos. 4.ed. São Paulo: IAL, 2008. http://www.ial.sp.gov.br/resources/editorinplace/ ial/2016_3_19/analisedealimentosial_2008.pdf. 18 Jun. 2020.

Instituto Brasileiro de Geografia e Estatística - IBGE. Indicadores IBGE. estatística da produção pecuária. Jan.-mar. 2020. Rio de Janeiro: IBGE, 2020a. 49p. https://biblioteca.ibge.gov.br/visualizacao/ periodicos/2380/epp_2020_1tri.pdf. 12 Jun. 2020.

Instituto Brasileiro de Geografia e Estatística - IBGE. Mapa das indicações geográficas. Cinco novos produtos são incluídos em projeto de propriedade industrial. 2020b. https:// agenciadenoticias.ibge.gov.br/agencia-noticias/2012-agenciade-noticias/noticias/22814-cinco-novos-produtos-sao-incluidosem-projeto-de-propriedade-industrial. 12 Jun. 2020.

Instituto Brasileiro de Geografia e Estatística - IBGE. Pesquisa de orçamentos familiares: 2008-2009. Análise do consumo alimentar pessoal no Brasil. Rio de Janeiro: IBGE, 2011. 150p. https://biblioteca. ibge.gov.br/visualizacao/livros/liv50063.pdf. 22 Jun. 2020.

Jardim-Botelho, A.; Gurgel, R.Q.; Henriques, G.S.; Santos, C.B.; Jordão, A.A.; Faro, F.N.; Souto, F.M.S.; Santos, A.P.R.; Cuevas, L.E. Micronutrient deficiencies in normal and overweight infants in a low socio-economic population in north-east Brazil, Paediatrics and International Child Health, v.36, n.3, p.198-202, 2016. https://doi.org/10.1179/2046905515Y.0000000035.
Jones, G.D.; Droz, B.; Greve, P.; Gottschalk, P.; Poffet, D.; McGrath, S.P.; Winkel, L.H.E. Selenium deficiency risk predicted to increase under future climate change. Proceedings of National Academy of Sciences, v.114, p.2848-2853, 2017. https://doi.org/10.1073/pnas.161157611

Kieliszek, M. Selenium - fascinating microelement, properties and sources in food. Molecules, v.24, n.7, e1298, 2019. https://doi. org/10.3390/molecules24071298.

Kieliszek, M.; Blazejak, S. Current knowledge on the importance of selenium in food for living organisms: a review. Molecules, v.21, n.5, e609, 2016. https://doi.org/10.3390/molecules21050609.

Ling, K.; Henno, M.; Jõudu, I.; Püssa, T.; Jaakson, H.; Kass, M.; Ots, M. Selenium supplementation of diets of dairy cows to produce Seenriched cheese. International Dairy Journal, v.71, p.76-81, 2017. https://doi.org/10.1016/j.idairyj.2017.03.004.

Mahan, L.K.; Escott-Stump, S.; Raymond, J.L. Krause. Alimentos, nutrição e dietoterapia. 12.ed.. Rio de Janeiro: Elsevier, 2012. 1351p.

Marques, K.H.S.R.; Carvalho, J.B.; Mesquita, A.A.; Silva, J.A.G.; Ferreira, S.V.; Sousa, T.L.; Egea, M.B.; Silva, M.A.P. Influência do tratamento térmico no rendimento e composição físico-química de queijos frescais. Brazilian Journal Of Development, v.6, n.4, p.19446-19460, 2020. https://doi.org/10.34117/bjdv6n4-203.

McSweeney, P.; Fox, P.; Cotter, P.; Everett, D. (Eds.). Cheese: chemistry, physics and microbiology. 4.ed. London: Academic Press, 2017. $1302 \mathrm{p}$.

Moatkhef, F.; Ismail, H.; Agamy, N.; Aborhyem, S. Quantitative determination of selenium in the most common food items sold in Egypt. Journal of the Egyptian Public Health Association, v.95, e15, 2020. https://doi.org/10.1186/s42506-020-00044-z.

O'Callaghan, Y.C.; O'Connor, T.P.; O'Brien, N.M. Nutritional aspects of cheese. In: Fox, P.F.; Guinee, T.P.; Cogan, T.M.; McSweeney, P.L.H. (Eds.). Fundamentals of cheese science. Boston: Springer, 2017. P.715-730. https://doi.org/10.1007/978-1-4899-7681-9_20.

Ogra, Y.; Ogihara, Y.; Anan, Y. Comparison of the metabolism of inorganic and organic selenium species between two selenium accumulator plants, garlic and Indian mustard. Metallomics, v.9, n.1, p.61-68, 2017. https://doi.org/10.1039/C6MT00128A.

Phipps, R.H.; Grandison, A.S.; Jones, A.K.; Juniper, D.T.; RamosMorales, E.; Bertin, G. Selenium supplementation of lactating dairy cows: effects on milk production and total selenium content and speciation in blood, milk and cheese. Animal, v.2, n.11, p.16101618, 2008. https://doi.org/10.1017/S175173110800298X.

Pilarczyk, B.; Tomza-Marciniak, A.; Mituniewicz-Małek, A.; WieczorekDąbrowska, M.; Pilarczyk, R.; Dmytrów, I. Selenium content in selected products of animal origen and estimation of the degree of cover daily Se requirement in Poland. International Journal of Food Science and Technology, v.45, n.1, p.186-191, 2010. https://doi.org/10.1111/j.1365-2621.2009.02120.x.

Pimentel, E.T. Qualidade de queijo coalho comercializado em Manaus, AM. Manaus: Universidade Federal do Amazonas, 2019. 51p. Master's Dissertation. https://tede.ufam.edu.br/handle/ tede/7584. 12 Jun. 2020.

Sant'ana, A.M.S.; Bezerril, F.F.; Madruga, M.S.; Batista, A.S.M.; Magnani, M.; Souza, E.L.; Queiroga, R.C.R.E. Nutritional and sensory characteristics of minas fresh cheese made with goat milk, cow milk, or a mixture of both. Journal of Dairy Science, v.96, n.12, p.7442-745, 2013. http://doi.org/10.3168/jds.2013-6915. 
Santos, M.; Silva, F.M.R.; Muccillo-Baisch, A. L. Selenium content of Brazilian foods: A review of the literature values. Journal of Food Composition Analysis, v.58, p.10-15, 2017. https://doi. org/10.1016/j.jfca.2017.01.001.

Seixas, V.N.Z.; Félix, M.R.; Silva, G.M.; Perrone, I.T.; Costa, R.G.B.; Carvalho, A.F. Characterization of Marajó cheese, cream type, in two seasons: Physicochemical and microbiological aspects. Revista do Instituto de Laticínios Cândido Tostes, v.69, n.2, p.89101, 2014. https://doi.org/10.14295/2238-6416.v69i2.327.

Semba, R. D.; Ricks, M. O.; Ferrucci, L.; Xue, Q. L.; Guralnik, J. M.; Fried, L. P. Low serum selenium is associated with anemia among older adults in the United States. European Journal of Clinical Nutrition, v. 63, p. 93-99, 2009. https://doi.org/10.1038/sj.ejcn.1602889.

Silva, F.F. Qualidade de produtos de origem animal. Curitiba: Atena Editora, 2019. 195p. https://doi.org/10.22533/at.ed.659191211.

Silva, B.P.P.; Oliveira, R.W.S.; Sousa, I. B.; Gomes, P.R.B.; Santos, S.J.L; Louzeiro, H.C. Nutritional composition of coalho cheese sold at free fairs in São Luis - MA. Brazilian Journal of Development, v.6, n.6, p.34043-34053, 2020. https://doi.org/10.34117/ bjdv6n6-088.

Silva, C.R.; Figueiredo, B.R.; Capitani, E.M.; Cunha, F.G. Geologia médica no Brasil: efeitos dos materiais e fatores geológicos na saúde humana, animal e meio ambiente. Rio de Janeiro: CPRM; Serviço Geológico do Brasil, 2006. 220p. http://www.cprm.gov. br/didote/pdf/Geologia_medica_Brasil.pdf. 19 Jun. 2020.

Silva, F.F. Qualidade de produtos de origem animal. Paraná: Atena Editora, 2019.
Silva, J.; Brustoline, C.R.; Ferreira, V.P.; Junior, L.S.; Mello, J.W.V.; Michereff Filho, M. Teor natural de selênio em solos do estado de Minas Gerais. In: Reunião Brasileira de Fertilidade do Solo e Nutrição de Plantas - FERTBIO 2012, 30., 2012, Maceió. Anais... Viçosa: Sociedade Brasileira de Ciência do Solo, 2012. https://ainfo.cnptia.embrapa.br/digital/bitstream/ item/73195/1/0000000553-FERTBIO-Juscimar.pdf. 29 Jun. 2020.

Średnicka-Tober, D.; Barański, M.; Seal, C.J.; Sanderson, R.; Benbrook, C.; Steinshamn, H.; Gromadzka-Ostrowska, J.; Rembiałkowska, E.; Skwarło-Sońta, K.; Eyre, M.; Cozzi, G.; Larsen, M.K.; Jordon, T.; Niggli, U.; Sakowski, T.; Calder, P.C. Burdge, G.C.; Sotiraki, S.; Stefanakis, A.; Stergiadis, S.; Yolcu, H.; Chatzidimitriou, E.; Butler, G.; Stewart, G.; Leifert, C. Higher PUFA and n-3 PUFA, conjugated linoleic acid, $\alpha$-tocopherol and iron, but lower iodine and selenium concentrations in organic milk: a systematic literature review and meta- and redundancy analyses. British Journal of Nutrition, v.115, n.6, p.1043-60, 2016. https://doi.org/10.1017/ s0007114516000349.

Tabela Brasileira de Composição de Alimentos - TACO. NEPA. UNICAMP. 4.ed. Campinas: NEPA; UNICAMP, 2011. 161p. http://www.nepa.unicamp.br/taco/contar/taco_4_edicao_ ampliada_e_revisada.pdf. 02 Aug. 2020.

United States Department of Agriculture - USDA. Agricultural Research Service. National nutrient database for standard reference. Beltsville: USDA, 2013. http://www.ars.usda.gov/ba/ bhnrc/ndl. 02 Jun. 2020. 